\title{
An Analysis of the Effective Path of Ideological and Political Education of College Students in the Background of New Media Industry Development
}

\author{
Xiaomin Liu ${ }^{1}$ and Yalin Wang, ${ }^{2, *}$ \\ ${ }^{1}$ Hubei University of Medicine, 442000 Shiyan, Hubei, China \\ ${ }^{2}$ Taihe Hospital, 442000 Shiyan, Hubei, China
}

\begin{abstract}
The rapid development of new media industry has not only changed the social network, but also set off a wave of change in many fields. At present, the new media industry has spread all over the society, and also caused scholars to think about the innovative reform of education.. The continuous progress of network technology has changed the learning and life style of college students, which not only broadens the channels for students to obtain outside information, but also strengthens the communication between students and teachers, and brings teachers and students closer together. As an important way to guide students' value orientation and cultivate students' discernment ability, teachers need to keep up with the development of new media, actively innovate educational methods, and also be alert to the challenges brought by new media technology to ensure the effectiveness of ideological education. This paper analyses the opportunity dilemma faced by ideological and political education in the context of new media, and proposes an effective path for education.
\end{abstract}

\section{Introduction}

Ideological and political education of college students is a complex system project, which has a special and important strategic position and role for a country. The important status and historical mission of the college student group determines that it is necessarily the main object of ideological and political education, and strengthening the ideological and political education of college students is a long-term strategic task for China. The current ideological and political education of college students is facing new changes due to the emergence of various new media tools. According to relevant reports, the proportion of college students among users of various social network applications in China is about $50 \%$ of the total number of users, and college students have become the main audience group of new media. Compared with traditional media, new media has special communication advantages and forms a complex new media environment. In this current era of rapid development of new media, college students with active thinking and good at accepting new things present new characteristics in the formation of ideological concepts, interpersonal communication and study life, which also brings new opportunities and challenges to college students' ideological and political education both in practice and theory.

College students are in the stage of gradual stabilization of their three views, so a slight mistake will make students' thoughts and behavioural quality deviate from the track, so it is extremely important to do a good job in ideological and political education. Under the influence of new media and network, the channels for college students to receive education are no longer limited to books, and students are more likely to learn information from the network, but the information in the network is mixed, and it is easy to mislead students' value orientation. Therefore, in order to avoid the negative influence of new media on college students in time, it is necessary to make use of the advantages of new media to carry out ideological and political education. At present, many colleges in China have started the reform pilot work at the practical and theoretical levels. At the practical level, most universities attach great importance to the influence of the rapidly developing new media on the ideological and political education, make full use of the advantages of information technology of universities, explore the ways and methods to improve the effectiveness of ideological and political education of college students in the new media era, and have achieved certain results. However, in the process of concrete practice, it is a fact that the effectiveness of ideological and political education of college students is not satisfactory. At the theoretical level, although Chinese academics are paying more and more attention to the issue of college students' ideological and political education, and related researches are gradually increasing, and many valuable research results have been made, there are some shortcomings, such as single or old research perspectives, lack of theoretical background and effective theoretical tools, mostly focusing on the abstract description of

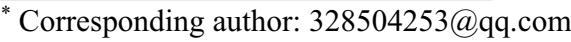


concepts or diagnostic conclusions, which makes the research results in practice This makes the research results in practice insufficient in operability and cannot fully adapt to the cognitive characteristics and value needs of college students in the rapidly changing new media era. Therefore, on the basis of the current research results, it is worthwhile to conduct an in-depth study on how to find an effective path for the ideological and political education of college students in the new media era.

\section{Characteristics of the new media era}

The new media era has the main characteristics of openness and immediacy, massive and compatibility, interactivity and equality, virtualness and concealment, influence and permeability.

First, the openness of the new media era is mainly manifested in the wide coverage of communication subjects, objects and the scope of communication. The new media environment transcends the various barriers that exist in traditional cross-regional information exchange, so that all kinds of ideological cultures can spread freely. The openness of the new media era can make ideological and political education widely available to all social strata, all groups and even everyone, making ideological and political education truly universal. The immediacy of the new media is demonstrated by its fast and time-sensitive transmission. New media use their own advantages to significantly reduce the time required for information dissemination, making it possible for information to spread quickly.

Secondly, the massive nature of the new media era is reflected in the fact that unlike traditional media, the new media is not limited in terms of space and broadcasting time, and its large amount of information, many types of data, and the speed of instantaneous data processing exceeds that of traditional media by tens of thousands of times. Compatibility is reflected in the multimedia of communication means. New media is compatible with the advantages of traditional media, not only with the characteristics of multi-media unity, but also with the characteristics of maintainability. The compatibility of the new media environment makes the information come alive and provides a new space for improving the attractiveness and effectiveness of ideological and political education.

Third, the interactivity of the new media era is reflected in the rich communication characteristics of the information receiving process, which can effectively realize information exchange. New Media era interactivity provides technical conditions for two-way interaction between educators and educated people and expands the space for ideological and political education. Equality is reflected in the new mode of free communication in information dissemination and exchange, where each user can freely publish, disseminate and receive information. The equality of the new media environment enhances the subjectivity of the educated in ideological and political education, which greatly stimulates the enthusiasm and initiative of college students to receive education.

Fourth, the virtual nature of the new media era is reflected in the fact that the existence of information in the new media environment is invisible and spread in the form of digital media. The virtual nature of the new media era allows educators and educated people in ideological and political education to interact equally without the restrictions of real identity and status. The concealment is reflected in the concealment of the identity of the communicator and the concealment of the substance of the communication content. The concealment in the new media era minimizes the resistance of college students in the process of ideological and political education, and makes the ideological and political education content more naturally accepted by college students.

Fifth, the influential nature of the new media era is reflected in the important role of the new media on the influence of ideological and political education. This influence makes the object of ideological and political education change from a small number of people to a large number of groups, and once the educational content is disseminated by new media, the influence is rapidly expanded and multiplied. Permeability is reflected in the process of unconsciously and deeply accepting information through new media technology. The permeability in the new media era makes the ideological and political education content quietly influence the college users and make the ideological and political education of college students more effective.

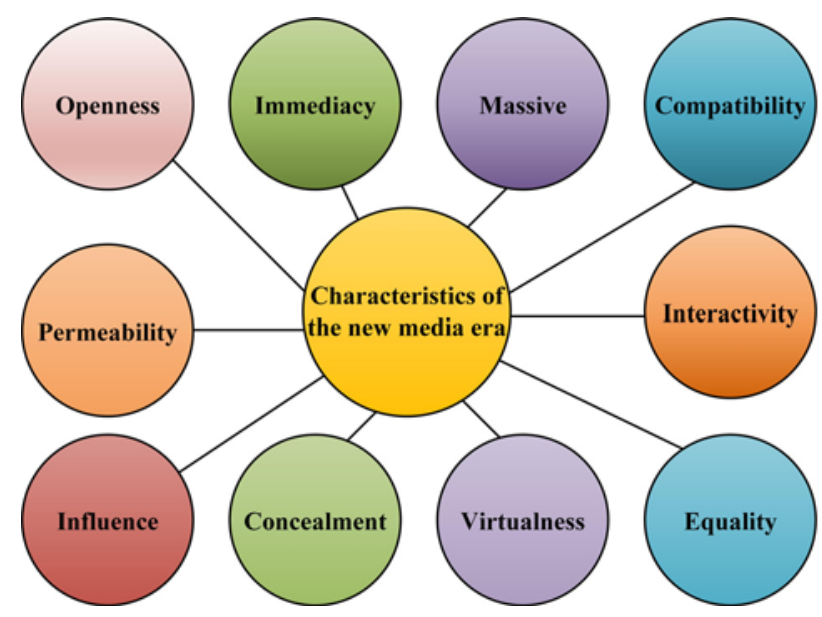

Fig. 1 Characteristics of the new media era

\section{Opportunities for ideological and political education of college students in the context of new media}

\subsection{Enriching ideological and political education forms}

New media has remarkable characteristics such as communication, interactivity and sharing, it has rich resources, and there are various new media platforms, such as microblogs, WeChat, public numbers and even 
Jitterbug, etc. Teachers can strengthen communication with students based on these media platforms and carry out ideological and political education to students, which can not only change the previous boring education mode, but also enrich the form of ideological and political education and can effectively improve the education effect [1]. Students' interest in ideological and political education can be improved through new media, and they can grasp more information and knowledge in a short time. For example, teachers can use microblogs to design educational topics and communicate with students interactively, which can not only grasp the situation of students' thoughts, but also make ideological and political education more interesting.

\subsection{The content of ideological and political education is expanded}

Ideological and political education workers and college students can use the new media to obtain information, transmit information and share information, and the information resources in the network are very extensive, and students and teachers can save the text, video, audio and pictures and other data information, which is very convenient for the integration of ideological and political education content and teaching, and greatly expands the content of ideological and political education [2]. In the traditional education mode of ideological and political education, teachers mostly teach based on the content of textbooks. Only teachers recognize the convenience brought by new media, base on textbooks but not limited to them to innovate educational content, meet students' learning needs, and ensure the real-time content of ideological and political education can stimulate students' interest in learning, which is also in line with the law of the development of the new media era. At the same time, when teachers use the information resources in the new media to carry out ideological and political education, they should do a good job of content screening to ensure that the educational content is in line with the mainstream values of the current society.

\subsection{Enhance the autonomy of college students in receiving education}

College students are important leaders in building socialism with Chinese characteristics. The convenience of new media can provide students with opportunities to participate in the construction of socialist democracy, and students can learn about national events and social hotspots in time in the network, and also have the right to freely comment and express their opinions. Under such a background, students no longer receive ideological and political education passively, but the new media can subconsciously penetrate the relevant educational contents into the minds of college students, and students can independently choose the information and learning resources they want to know, and they can also give feedback on their learning results at any time, which greatly enhances the autonomy of college students in receiving education, and can also effectively cultivate the habit of self-education of college students. This greatly enhances the autonomy of college students in receiving education and also effectively cultivates the habit of self-education.

\section{The effective path of college students' ideological and political education in the background of new media}

\subsection{Change education concept and improve teachers' media literacy}

The progress of new media era makes it an inevitable trend for college teachers to learn and use new media technology to carry out ideological and political education. In order to effectively improve the effectiveness of ideological and political education of college students, teachers should grasp the opportunities brought by the new media era, fully respect students' self-awareness in education and teaching, meet students' learning needs, change the traditional education concept and innovate it, and also effectively improve their own media literacy. This requires pre-service training for college teachers and the implementation of relevant educational conferences to ensure the suitability of conference training contents with new media information, and also regularly organize teachers to participate in new media teaching exchange meetings, and colleges and universities can also invite relevant experts and scholars to hold seminars to improve teachers' attention to new media teaching and ensure that they can understand the advantages of new media teaching, so that when carrying out ideological and political education effectively use the new media technology. Secondly, since teachers occupy the main position in ideological and political education, their media literacy and professional ability are related to the effect of classroom teaching, so teachers also need to pay attention to the improvement of their own media literacy, keep pace with the development of the new media era, timely learn how to use new media tools such as the Internet and cell phones and apply them flexibly in ideological and political education, and strive to improve their own media literacy so as to effectively improve the effect of ideological and political education for college students.

\subsection{Optimize classroom teaching with the help of new media technology}

In the background of new media era, although colleges and universities, teachers and students are changing the way and means of ideological and political education, but no matter what, teaching of ideological and political theory class has always been the main channel for students to correctly understand and know Marxism and socialism theory with Chinese characteristics, and the ideological and political education of college students still has to keep the main position of traditional ideological and political education, which is the ideological and political class, with optimizing the 
classroom teaching as the main goal and task. classroom teaching as the main goal and task [3]. In the actual classroom teaching, teachers should flexibly apply new media technology to enhance the interest of the classroom of Civic and Political Education, supplement the content of the textbook with the rich information resources in the Internet, effectively expand the teaching content, enhance the guidance of Civic and Political Education to students, and enable students' subjective initiative to be fully developed. At the same time, teachers should also pay attention to the selection of expanded content, always adhere to the main theme of Marxism and socialism with Chinese characteristics theory, and strictly prohibit the transmission of nonmainstream values of teaching content to students to ensure the rigor of ideological and political education of college students.

\subsection{Using new media to build a platform for ideological and political education}

The dissemination mode of network information is more diversified and faster. Colleges and teachers should make use of these two features to grasp the network and use new media to build an ideological and political education platform, so as to create a broader space for students' ideological and political learning. Teachers should constantly adjust and optimize the establishment of the education platform, the content should integrate the information related to the construction of campus culture, and also enrich the content of ideological and political education, and then set up diverse columns to highlight the characteristics of ideological and political education, focusing on setting up a hot news column to ensure that the content in this column covers the latest current affairs and politics, social hotspots, hot topics, etc., to enhance the timeliness of ideological and political education, which can also The content of ideology and politics can be integrated with each other and various disciplines, and finally, the information column of college students' employment information and club activities should be set up, so as to enhance the attractiveness of the education platform to students [4]. Teachers can also use the platform to carry out online ideological and political education online classes, shoot and broadcast propaganda videos of ideological and political education on the platform, and use the function of live broadcast in the platform to broadcast campus activities related to socialist core values live, etc., so as to enhance students' participation in receiving ideological and political education in the network and highlight the characteristics of living ideological and political education. In addition, teachers can also make use of the virtual nature of the Internet to establish good communication with students through the chat rooms in the platform, timely solve students' confusion in life or study, or help students with career planning, so that students can invariably receive the inculcation of ideological and political education and thus shape the correct values. It is also necessary to make use of the characteristics of students who like to surf the Internet, to conduct regular thematic class meetings in the platform, to improve students' ability to discern information on the Internet, to make students understand the harm brought by bad information in the Internet, and also to strengthen the education of students on Internet laws and regulations, to enhance students' self-discipline awareness of using the Internet [5].

\section{Conclusion}

To sum up, ideological and political education plays an important role in cultivating moral quality, political literacy and values of college students, and can cultivate talents for society and the country to build socialist modernization with Chinese characteristics. In the face of the continuous development of the new media era, teachers should have a comprehensive understanding of the opportunities and dilemmas facing ideological and political education, promote the high degree of integration of new media and ideological and political education, improve the effectiveness of ideological and political education for college students, and ensure the effective penetration of ideological and political education for college students.

\section{References}

1. Wan Dandan, Wang Jiucai. Opportunities, challenges and countermeasures of ideological and political education of college students in the context of new media. Economist,2021(5):192-192+194.

2. Chang Weifeng. On the application of new media platform in the ideological and political education of college students. Journal of Hubei Institute of Science and Technology,2021,41(1):9-12.

3. Jiao Xiaojun, Wang Guixin, Tan Wanjun. Research on the innovation of ideological and political education of college students in the context of new media. Journal of Changchun Normal University,2019,38(11):4-5.

4. Liu Huan. Research on measures of ideological and political education of college students in the new media perspective. New Silk Road:Mid,2021(4):0101-0102.

5. Yang Chunxiang. Challenges and innovation of ideological and political education of college students in the new media environment. Industry and Technology Forum,2020(17):254-255. 